УДК 551.352

Mart SAARSO

\title{
ADVECTIVE FORMATION OF MID-DEPTH NEPHELOID LAYER IN AN UNDERWATER CHANNEL
}

\begin{abstract}
Results of a sediment trap experiment in an underwater channel are presented. On the basis of vertical particulate inorganic flux measurements at two stations and limited hydrographical data a possible formation mechanism of a mid-depth nepheloid layer is described. We suggest that the bottom nepheloid layer was advected towards the deeper part of the channel and detached from the bottom by isopycnal surface. This consideration is supported by size distribution parameters of the settling material.
\end{abstract}

\section{Introduction}

Mid-depth maximums are described in most of the studies of suspended particulate matter distribution in the World Ocean. The formation processes of these phenomena are generally understood, but it is not always possible to make direct measurements. This paper presents the results of a sediment trap experiment, carried out in an underwater channel in the Baltic Sea. On the basis of these data a possible formation mechanism of a mid-depth nepheloid layer by advection of resuspended slope sediments is described.

The distribution of suspended particulate matter in the Baltic Sea depends mainly on two factors: biological productivity and the transport mechanism of terrigenous particles from coastal and other shallow water regions towards the deeper sea areas. The latter is controlled by the physical properties of the marine environment, which is the main controller of the formation of vertical flux of inorganic particles. The total value and the size distribution of this flux are functions of physical transport processes and characterize the settling conditions.

Consequently, these two parameters of inorganic flux can be considered as a direct natural expression of the physical properties of a particular marine environment.

Inorganic sediment suspended in seawater is unstable as single mineral grains and occurs as a mixture of flocculated aggregates and single grains forming the particle size distribution (PSD) while the grain size distribution (GSD) corresponds to the size of deflocculated inorganic grains. The role of flocculation in sedimentation processes has been well described by Kranck (1975), who has developed an equation, relating the modal diameters of PSD and GSD:

$$
\log (\text { grain mode })=-0.58+1.30 \log (\text { floc mode })
$$

Kranck has shown that both, grains forming the mode of GSD and larger, settle as individual grains whereas grains smaller than the modal size are mostly parts of flocs.

The advantage of measuring GSD is that their spectra do not change in sediment traps and water samplers during sample storage and processing. For that reason we have used GSD as a basic property for characterizing the size distribution. 


\section{Field experiments}

The Baltic 1 type sediment traps used in this study are fibreglass plastic open cylinders $11.5 \mathrm{~cm}$ in diameter with height to diameter ratio of $6: 1$. The shape factor was chosen according to the results obtained by Hargrave and Burns (1979) and Gardner $(1980 a, b)$, to collect maximum quantity of settling material and to prevent loss of the sample due to resuspension during recovery in rough weather conditions.

Bottom topography of the study area and the locations of sediment trap stations are shown in Fig. 1. Two arrays with traps at 2, 5 and 10 meters above bottom (mab) at water depths of $38.5 \mathrm{~m}$ (station GR-1) and $31.5 \mathrm{~m}$ (station GR-2) were moored from RV Kiir for 10 days, from September 14 to 24,1984 . During deployment and recovery operations temperature profiles were recorded with Tsurumi Seiki bathythermograph.

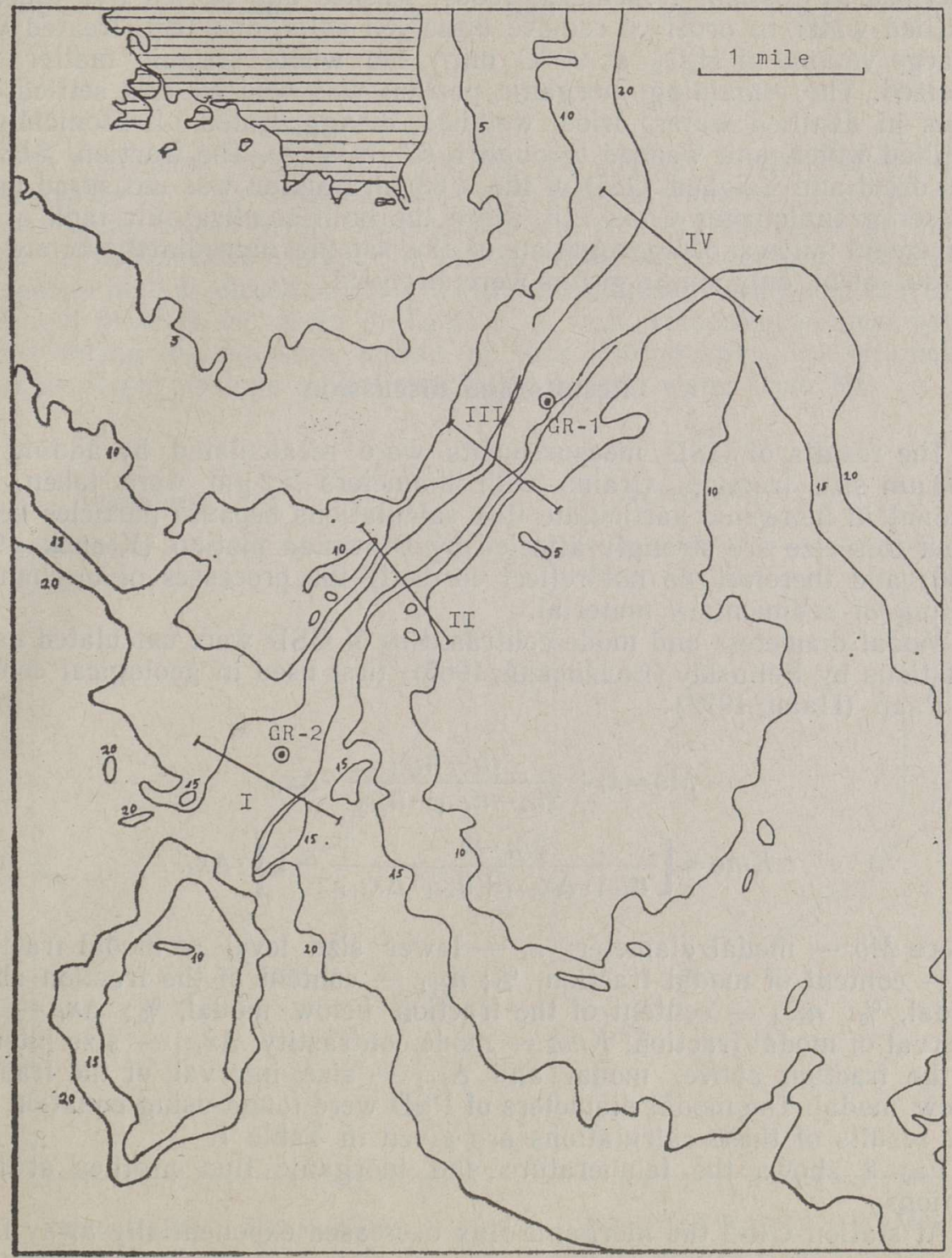

Fig. 1. Bottom topography of the study area and the locations of sediment trap stations. I-IV are the echo sounder cross-sectional profiles. Depths are given in meters. 
Current direction and velocity were measured on September 14 at GR-2 at four depths with a VMM type current meter, which enabled to measure average parameters of 15 to 20 minutes. To learn better the bottom topography of the study area, four echo sounder cross-sectional profiles of the channel were recorded.

After recovery the sediment traps with samples were transported to a coastal laboratory, where the samples were packed into polyethylene bottles and fixed with formaline. The whole content of each sediment trap was included in the sample.

\section{Laboratory procedures}

The sediment trap samples were settled in glass cylinders as generally described by Lisitzin (Лисицын, 1956), washed and settled five times in distilled water in order to remove dissolved salts, and then treated with a large volume of $\mathrm{H}_{2} \mathrm{O}_{2}$ at $90^{\circ} \mathrm{C}$ until the whole organic matter was oxidized. The remaining inorganic portion was washed and settled five times in distilled water, dried, weighed, disaggregated ultrasonically in distilled water, and washed through a $63 \mu \mathrm{m}$ sieve. The fraction $>63 \mu \mathrm{m}$ was dried and weighed. GSD of the $<63 \mu \mathrm{m}$ fraction was measured using a laser granulometer Cilas 715. Since the built-in ultrasonic tank of the instrument allows disaggregation of the sample immediately before the measurement, only single grains were analysed.

\section{Results and discussion}

The results of GSD measurements were recalculated by adding the $>63 \mu \mathrm{m}$ size fraction. Grains with diameters $>2 \mu \mathrm{m}$ were taken into account in inorganic particulate flux calculations because particles below about this size are strongly affected by Brownian motion (Kranck, 1975; 1980) and therefore do not reflect correctly the processes of mechanical sorting of sedimentary material.

Modal diameters and mode contrastities of GSD were calculated using equations by Belinskiy (Белинский, 1965), first used in geological context by Рaap (Паап, 1972):

$$
\begin{gathered}
M o=x_{i}+\frac{n_{i}-n_{i-1}}{2 n_{i}-n_{i-1}-n_{i+1}} \cdot \Delta x_{i} \\
K m o=\left[\frac{2 n_{i} \cdot x_{i}}{n_{i-1} \cdot \Delta x_{i-1}+n_{i+1} \cdot \Delta x_{i+1}}-1\right] \cdot \Delta x_{i}
\end{gathered}
$$

where Mo - modal diameter; $x_{i}$ - lower size level of modal fraction; $n_{i}$ - content of modal fraction, $\% ; n_{i+1}$ - content of the fraction above modal, $\% ; n_{i-1}$ - content of the fraction below modal, $\% ; \Delta x_{i}-$ size interval of modal fraction; Kmo - mode contrastity; $\Delta x_{i+1}-$ size interval of the fraction above, modal and $\Delta_{i-1}-$ size interval of the fraction below modal. The modal diameters of PSD were found using equation (1). The results of these calculations are given in Table 1 .

Fig. 2 shows the temperature and inorganic flux profiles at both stations.

At station GR-2 the inorganic flux decreased exponentially away from the bottom, indicating an occurrence of resuspension-generated bottom nepheloid layer. At station GR-1 a remarkable maximum was measured at $5 \mathrm{mab}$ while at 2 and $10 \mathrm{mab}$ the flux was more than twice lower. 
Vertical flux of different size classes and size distribution parameters calculated using equations (1), (2) and (3)

\begin{tabular}{|c|c|c|c|c|c|c|}
\hline \multirow[b]{2}{*}{ Size, $\mu \mathrm{m}$} & \multicolumn{6}{|c|}{ Inorganic flux, $\mathrm{mg} / \mathrm{m}^{2} /$ day } \\
\hline & $\begin{array}{l}\text { GR-1 } \\
2 \mathrm{mab}\end{array}$ & $\begin{array}{l}\text { GR-1 } \\
5 \mathrm{mab}\end{array}$ & $\begin{array}{l}\text { GR-1 } \\
10 \mathrm{mab}\end{array}$ & $\begin{array}{l}\text { GR-2 } \\
2 \mathrm{mab}\end{array}$ & $\begin{array}{l}\text { GR-2 } \\
5 \mathrm{mab}\end{array}$ & $\begin{array}{l}\text { GR-2 } \\
10 \mathrm{mab}\end{array}$ \\
\hline $\begin{array}{r}2-4 \\
4-8 \\
8-16 \\
16-32 \\
32-63 \\
>63 \\
>2\end{array}$ & $\begin{array}{r}1005 \\
956 \\
654 \\
400 \\
556 \\
351 \\
3922\end{array}$ & $\begin{array}{r}2898 \\
3756 \\
1746 \\
507 \\
468 \\
293 \\
9668\end{array}$ & $\begin{array}{r}429 \\
439 \\
429 \\
810 \\
478 \\
224 \\
2810\end{array}$ & $\begin{array}{r}5024 \\
7405 \\
4263 \\
1707 \\
1434 \\
771 \\
20605\end{array}$ & $\begin{array}{r}2420 \\
3161 \\
1805 \\
537 \\
654 \\
302 \\
8878\end{array}$ & $\begin{array}{r}634 \\
820 \\
449 \\
146 \\
127 \\
68 \\
2244\end{array}$ \\
\hline $\begin{array}{l}\text { Mo } \\
\text { Kmo } \\
\text { Floc Mo }\end{array}$ & $\begin{array}{l}3.9 \\
0.2 \\
8.0\end{array}$ & $\begin{array}{l}5.2 \\
2.1 \\
9.9\end{array}$ & $\begin{array}{r}24.6 \\
6.4 \\
32.8\end{array}$ & $\begin{array}{r}5.8 \\
1.3 \\
10.8\end{array}$ & $\begin{array}{r}5.4 \\
1.4 \\
10.2\end{array}$ & $\begin{array}{r}5.4 \\
1.5 \\
10.2\end{array}$ \\
\hline
\end{tabular}

The measured temperature profiles are typical of the Baltic Sea at such depths in early autumn. The water column was stratified into three layers: upper mixed layer, thermocline, and cold bottom layer. At station GR-2 the thermocline reached the bottom as the water depth in the channel decreases in SW direction. The depth maximums of echo sounder crosssectional profiles are given in Table 2. A weak coldening of near-bottom water during the exposure period at this station may be explained by possible slight upslope advection of cold bottom water from NE.
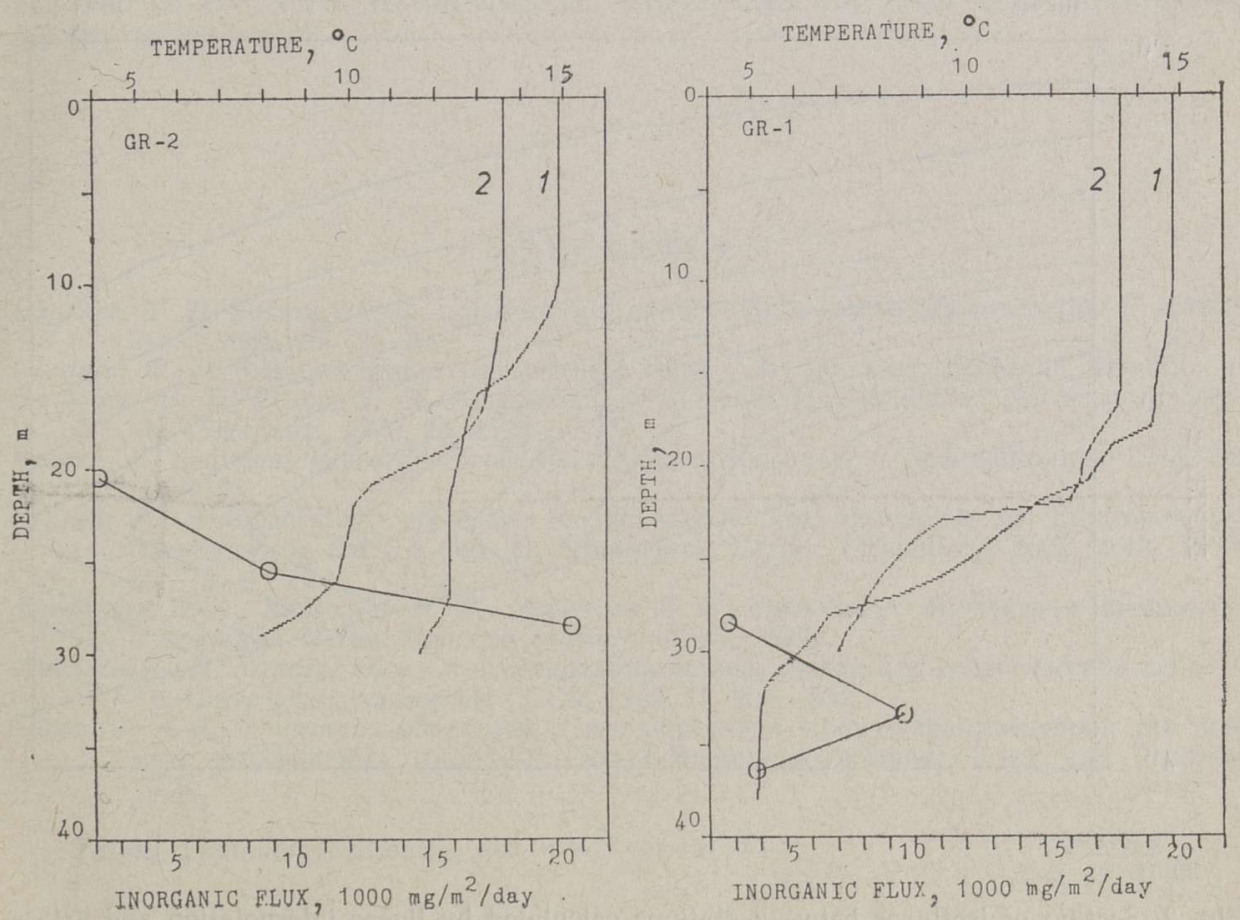

Fig. 2. Inorganic flux and temperature profiles on Sept. 14 (1) and Sept. 24 (2). 
Maximum depths of echo sounder cross-sectional profiles

\begin{tabular}{l|l}
\hline Profile No. & Max. depth, m \\
\hline
\end{tabular}

Results of current measurements made on September 14 at Station GR-2

\begin{tabular}{l|l|l}
\hline Depth, m & Direction, deg. & Velocity, cm/s \\
\hline
\end{tabular}

$\begin{array}{rrr}15 & 104 & 5.9 \\ 20 & 66 & 9.8 \\ 25 & 63 & 4.3 \\ 28 & 72 & 4.3\end{array}$

The results of the current measurements are given in Table 3 indicating a correlation between the current direction and bottom topography. This brings about a NE-directed inflow to the channel in the water layer below $20 \mathrm{~m}$ at station GR-2.

Although the number of temperature and current measurements is very limited, we assume that the hydrographic conditions were rather stable as there were no significant changes in the meteorological conditions during the exposure period.

According to the temperature profiles at station GR-1 the 5 mab trap was situated at the lower boundary of the thermocline layer, while the 10 mab trap stayed in the thermocline. However, there might exist some vertical migrations of the thermocline, caused by internal waves. As to

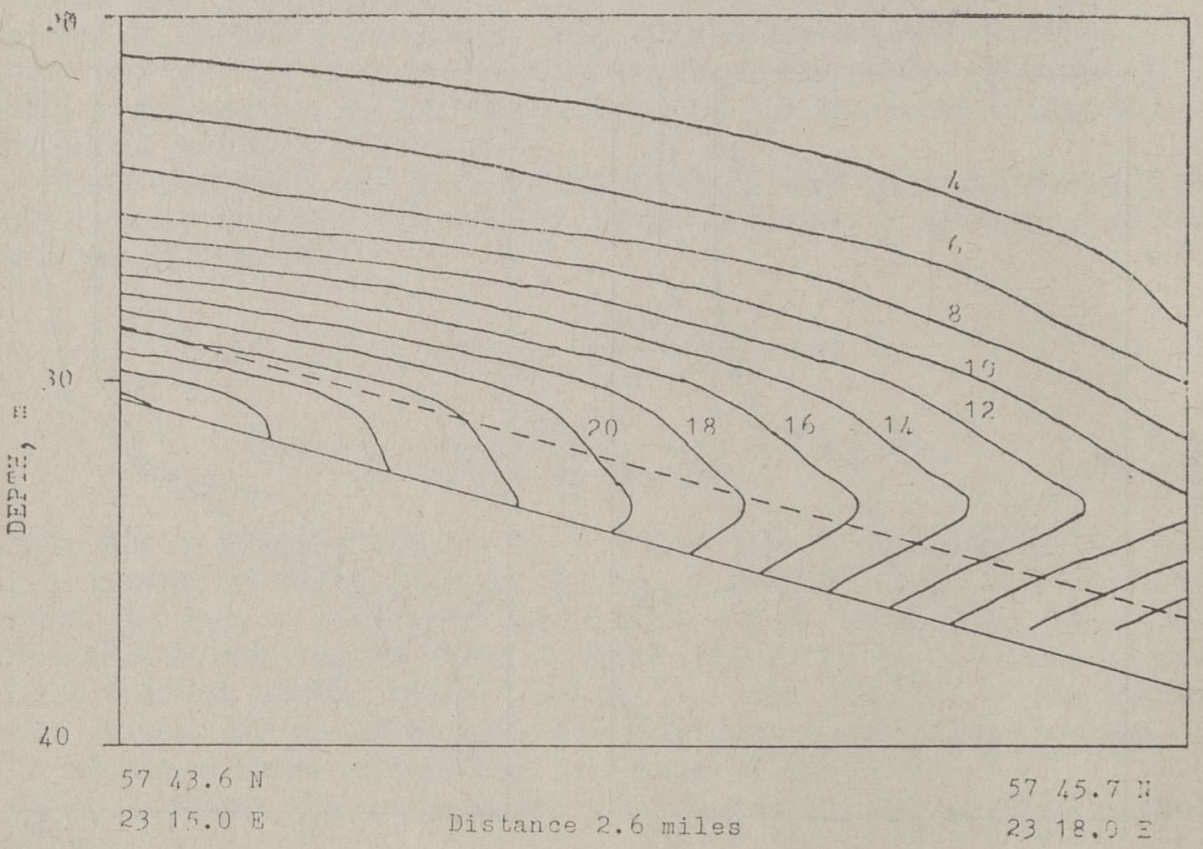

Fig. 3. Section of isofluxes between stations calculated by linear interpolation and extrapolation. The dashed line indicates $2 \mathrm{~m}$ height above bottom, flux values are given in thousands. 
the measured current directions the bottom nepheloid layer at station GR-2 had to be advected towards the deeper part of the channel, forming the above-mentioned flux maximum at GR-1.

This consideration is supported by the results of GSD modal diameters and mode contrastities calculations. These data indicate that the $5 \mathrm{mab}$ flux maximum at GR-1 originated from the bottom nepheloid layer at GR-2 as the GSD modes and mode contrastities of these samples have very close values. A slight decrease of GSD mode $(-0.2 \mu \mathrm{m})$ and an increase in the mode contrastity $(0.7)$ can be explained respectively as results of progressive sedimentation and mechanical sorting of the material during advection through the channel. The calculated values of floc modes also confirm this explanation of advective formation of the middepth nepheloid layer.

To give a visualization of the described process, a section of isofluxes between stations was calculated by linear interpolation and extrapolation (Fig. 3).

\section{Conclusive summary}

On the basis of limited data and some assumptions we have tried to demonstrate a formation mechanism of a mid-depth nepheloid layer by cross-slope advection towards the higher depths. The result of this process is the detachment of nepheloid layer from the bottom by isopycnal surface. Although conditions of the given case are rather specific we suppose that our results describe a process which is of general importance in suspended sediment transport and may occur with significant variations. Our data suggest that size distribution parameters can be used as tracers for following the paths of suspended sediments.

Acknowledgements. I thank Captain Heino Afanasjev and the crew of RV Kiir for their assistance during field experiments. Sincere thanks are due to Dr. Villu Astok and Dr. Jüri Elken for their critical remarks on the manuscript.

\section{R E F ER E N C E S}

Gardner, W. D. Sediment trap dynamics and calibration: a laboratory evaluation // J. Mar. Res., $1980 a, 38,17-39$.

Gardner, W. D. Field assessment of sediment traps // J. Mar. Res., 1980b, 38, 41-52.

Hargrave, B. T., Bruns, N. M. Assessment of sediment trap collection efficiency // Limnol. Oceanogr., 1979, 24, 1124-1136.

Kranck, K. Sediment deposition from flocculated suspensions // Sedimentology, 1975, 22, $111-123$.

Kranck, $K$. Sedimentation processes in the sea // The Handbook of Environmental Chemistry, 2, Part A (ed. O. Hutzinger). Berlin; Heidelberg; New York, 1980, $61-75$.

Белинский В. А., Калихман И. Л., Майстров Л. Е., Митькин А. М. Высшая математика с основами математической статистики. М., 1965.

Лисищын А. П. Методы сбора и исследования водной взвеси для геологических целей // Тр. Ин-та океанологии АН СССР, 1956, 19, 204-231.

Пaan Ю. А.-A. О методах обработки и интерпретации данных гранулометрии (на примере четвертичных отложений Северо-Восточной Әстонии). Канд. дис. Таллинн, 1972.

Tallinn Technical University

Received

Feb. 15, 1990 
NEFELOIDSE VAHEKIHI ADVEKTIIVNE TEKE VEEALUSES KANALIS

On esitatud veealuses kanalis settepüüdjatega tehtud eksperimendi tulemused. Kahes jaamas mõõdetud anorgaaniliste osakeste vertikaalse voo ja piiratud hüdroloogiliste andmete põhjal on kirjeldatud nefeloidse vahekihi võimalikku tekkemehhanismi. Põhjalähedane nefeloidne kiht levis advektsiooni teel kanali sügavama osa suunas ning selle rebis põhjast lahti samatiheduspind. Seda väidet kinnitavad settiva materjali suurusjaotuse parameetrid.

\section{Mapt CAAPCO}

\section{АДВЕКТИВНОЕ ОБРАЗОВАНИЕ НЕФЕЛОИДНОИ ПРОСЛОИКИ В ПОДВОДНОМ КАНАЛЕ}

Представлены результаты эксперимента с седиментационными ловушками в подводном канале. На основе измерений вертикального неорганического осадочного потока на двух станциях и ограниченных гидрологических данных описан возможный механизм формирования промежуточного нефелоидного слоя. Предположено, что придонный нефелоидный слой распространялся путем адвекции в направлении более глубокой части канала и был отъединен от дна изопикнической поверхностью. Эта точка зрения подтверждается параметрами гранулометрического состава оседающего материала. 